\title{
Aerosol- and updraft-limited regimes of cloud droplet formation: influence of particle number, size and hygroscopicity on the activation of cloud condensation nuclei (CCN)
}

\author{
P. Reutter ${ }^{1,2}$, H. Su ${ }^{1}$, J. Trentmann ${ }^{2, *}$, M. Simmel ${ }^{3}$, D. Rose $^{1}$, S. S. Gunthe ${ }^{1}$, H. Wernli ${ }^{2}$, M. O. Andreae ${ }^{1}$, and \\ U. Pöschl ${ }^{1}$ \\ ${ }^{1}$ Max Planck Institute for Chemistry, Biogeochemistry Department, Mainz, Germany \\ ${ }^{2}$ Institute for Atmospheric Physics, Johannes Gutenberg University Mainz, Mainz, Germany \\ ${ }^{3}$ Leibniz Institute for Tropospheric Research, Leipzig, Germany \\ *now at: German Weather Service, DWD Offenbach, Germany
}

Received: 3 March 2009 - Published in Atmos. Chem. Phys. Discuss.: 1 April 2009

Revised: 24 July 2009 - Accepted: 17 August 2009 - Published: 24 September 2009

\begin{abstract}
We have investigated the formation of cloud droplets under pyro-convective conditions using a cloud parcel model with detailed spectral microphysics and with the $\kappa$-Köhler model approach for efficient and realistic description of the cloud condensation nucleus (CCN) activity of aerosol particles. Assuming a typical biomass burning aerosol size distribution (accumulation mode centred at $120 \mathrm{~nm}$ ), we have calculated initial cloud droplet number concentrations $\left(N_{C D}\right)$ for a wide range of updraft velocities $\left(w=0.25-20 \mathrm{~m} \mathrm{~s}^{-1}\right)$ and aerosol particle number concentrations $\left(N_{C N}=200-10^{5} \mathrm{~cm}^{-3}\right)$ at the cloud base. Depending on the ratio between updraft velocity and particle number concentration $\left(w / N_{C N}\right)$, we found three distinctly different regimes of $\mathrm{CCN}$ activation and cloud droplet formation:
\end{abstract}

(1) An aerosol-limited regime that is characterized by high $w / N_{C N}$ ratios $\left(>\approx 10^{-3} \mathrm{~m} \mathrm{~s}^{-1} \mathrm{~cm}^{3}\right)$, high maximum values of water vapour supersaturation $\left(S_{\max }>\approx 0.5 \%\right)$, and high activated fractions of aerosol particles $\left(N_{C D} / N_{C N}>\approx 90 \%\right)$. In this regime $N_{C D}$ is directly proportional to $N_{C N}$ and practically independent of $w$.

(2) An updraft-limited regime that is characterized by low $w / N_{C N}$ ratios $\left(<\approx 10^{-4} \mathrm{~m} \mathrm{~s}^{-1} \mathrm{~cm}^{3}\right)$, low maximum values of water vapour supersaturation $\left(S_{\max }<\approx 0.2 \%\right)$, and low activated fractions of aerosol particles $\left(N_{C D} / N_{C N}<\approx 20 \%\right)$. In this regime $N_{C D}$ is directly proportional to $w$ and practically independent of $N_{C N}$.

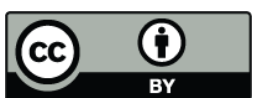

Correspondence to: $\mathrm{H}$. Su (hsu@mpch-mainz.mpg.de)
(3) An aerosol- and updraft-sensitive regime (transitional regime), which is characterized by parameter values in between the two other regimes and covers most of the conditions relevant for pyro-convection. In this regime $N_{C D}$ depends non-linearly on both $N_{C N}$ and $w$.

In sensitivity studies we have tested the influence of aerosol particle size distribution and hygroscopicity on $N_{C D}$. Within the range of effective hygroscopicity parameters that is characteristic for continental atmospheric aerosols $(\kappa \approx 0.05-0.6)$, we found that $N_{C D}$ depends rather weakly on the actual value of $\kappa$. A compensation of changes in $\kappa$ and $S_{\max }$ leads to an effective buffering of $N_{C D}$. Only for aerosols with very low hygroscopicity $(\kappa<0.05)$ and also in the updraft-limited regime for aerosols with higher than average hygroscopicity $(\kappa>0.3)$ did the relative sensitivities $\partial \ln N_{C D} / \partial \ln \kappa \approx\left(\Delta N_{C D} / N_{C D}\right) /(\Delta \kappa / \kappa)$ exceed values of $\sim 0.2$, indicating that a $50 \%$ difference in $\kappa$ would change $N_{C D}$ by more than $10 \%$.

The influence of changing size distribution parameters was stronger than that of particle hygroscopicity. Nevertheless, similar regimes of CCN activation were observed in simulations with varying types of size distributions (polluted and pristine continental and marine aerosols with different proportions of nucleation, Aitken, accumulation, and coarse mode particles). In general, the different regimes can be discriminated with regard to the relative sensitivities of $N_{C D}$ against $w$ and $N_{C N}\left(\partial \ln N_{C D} / \partial \ln w\right.$ and $\left.\partial \ln N_{C D} / \partial \ln N_{C N}\right)$. We propose to separate the different regimes by relative sensitivity ratios, $\left(\partial \ln N_{C D} / \partial \ln w\right) /\left(\partial \ln N_{C D} / \partial \ln N_{C N}\right)$ of $4: 1$ and $1: 4$, respectively.

Published by Copernicus Publications on behalf of the European Geosciences Union. 
The results of this and related studies suggest that the variability of initial cloud droplet number concentration in convective clouds is mostly dominated by the variability of updraft velocity and aerosol particle number concentration in the accumulation and Aitken mode. Coarse mode particles and the variability of particle composition and hygroscopicity appear to play major roles only at low supersaturation in the updraft-limited regime of CCN activation $\left(S_{\max }<0.2 \%\right)$.

\section{Introduction}

Clouds cover about $60 \%$ of the Earth's surface and have a strong influence on the global radiative balance, water cycle and climate (IAPSAG, 2007; IPCC, 2007). Deep convective clouds play an important role in the vertical redistribution of energy and moisture, especially in the tropics (Wang, 2003; Jiang et al., 2004). At mid-latitudes, deep convection is often associated with heavy rain events and severe weather. Hence, modifications of convective cloud properties can affect weather and climate on local and global scales (Rosenfeld, 2006).

A crucial factor for the dynamical and microphysical evolution of clouds is the activation of aerosol particles as cloud condensation nuclei (CCN), i.e., their hygroscopic growth into aqueous droplets that can freely grow by condensation of water vapor. Enhancing the number of aerosol particles that can serve as $\mathrm{CCN}$ generally leads to more and smaller cloud droplets at cloud base. It is well established that for shallow clouds, the precipitation efficiency is reduced when the aerosol concentration increases (e.g. Rosenfeld et al., 2000; Penner et al., 2004; Andreae and Rosenfeld, 2008). For deep convective clouds, the consequences of enhanced aerosol concentration are nonlinear and depend strongly on meteorological parameters (e.g. Khain et al., 2008; Rosenfeld et al., 2008).

Transport through deep convective clouds has been identified as a relevant source for upper tropospheric/lower stratospheric (UT/LS) aerosol (e.g. Andreae et al., 2001; Wang, 2003; Luderer et al., 2006). The number of aerosol particles released into the UT/LS region depends on the number of activated aerosol particles and on the microphysical evolution of deep convective clouds (nucleation and precipitation scavenging), which, in turn, is also modified by aerosol activation at cloud base.

Pyro-convection, i.e., deep convective clouds that form above wildfires, is one of the most extreme forms of atmospheric deep convection. Observational and modeling studies have shown the extraordinary dynamical and microphysical properties of deep pyro-clouds (e.g. Fromm and Servranckx, 2003; Fromm et al., 2005; Trentmann et al., 2006; Rosenfeld et al., 2007) and their ability to transport substantial amounts of aerosol into the UT/LS (Fromm et al., 2005; Luderer et al., 2007). However, the relevant processes in pyro-clouds, including $\mathrm{CCN}$ activation at the cloud base, are not yet fully characterized and understood.

The main parameters governing $\mathrm{CCN}$ activation and initial cloud droplet growth are the number, size and hygroscopicity of aerosol particles as well as the updraft velocity at the cloud base and the resulting water vapour supersaturation. In most earlier studies of cloud droplet formation, the number concentration of aerosol particles did not exceed $10^{4} \mathrm{~cm}^{-3}$ (e.g. Hjelmfelt et al., 1978; Hegg, 1999; Nenes et al., 2001; Feingold, 2003; Lance et al., 2004; Lohmann et al., 2004; Ervens et al., 2005; Segal and Khain, 2006; Kivekas et al., 2008; Cubison et al., 2008; Altaratz et al., 2008). This is realistic for regions with low or moderate air pollution, but in biomass burning plumes the aerosol particle number concentrations can reach up to $\sim 10^{5} \mathrm{~cm}^{-3}$ (Andreae et al., 2004; Reid et al., 2005; Janhäll et al., 2009).

To investigate and characterize the process of $\mathrm{CCN}$ activation in convective clouds, we have performed cloud parcel model simulations for a wide range of conditions, including the high updraft velocities and aerosol particle number concentrations observed over wildfires $\left(0.25-20 \mathrm{~m} \mathrm{~s}^{-1}\right.$, $200-10^{5} \mathrm{~cm}^{-3}$ ). Moreover, we have implemented and tested the $\kappa$-Köhler model approach as an efficient and realistic new way of describing the $\mathrm{CCN}$ activity of aerosol particles with complex chemical composition as emitted from biomass burning (Petters and Kreidenweis, 2007; Pöschl et al., 2009), rather than using unrealistic surrogate species like sodium chloride (e.g., Segal and Khain, 2006).

In Sect. 2 of this paper we describe the applied cloud parcel and Köhler models (hygroscopicity parameter and osmotic coefficient formalisms), and we present the results of test calculations performed for comparison and validation against an alternative cloud parcel model with spectral microphysics (Segal and Khain, 2006). In Sect. 3 we present and discuss the results of model calculations exploring the dependence of cloud droplet number concentration on updraft velocity and aerosol particle number concentration as well as particle size and hygroscopicity.

\section{Methods}

\subsection{Cloud parcel model}

The cloud parcel model used in this study has been developed by Simmel et al. (2002) and contains a detailed spectral description of cloud microphysics (Simmel and Wurzler, 2006; Diehl et al., 2006, 2007). Based on a given dry aerosol size distribution, the model initially calculates the equilibrium aerosol size distribution at the relative humidity prescribed for the start of the simulation. As the air parcel rises with a prescribed vertical velocity, the model simulates the expansion and cooling of air as well as the resulting changes in relative humidity and the related hygroscopic growth of aerosol particles and further condensational growth of cloud 
droplets. Collision-coalescence and entrainment processes were not included in our simulations, which are focused on $\mathrm{CCN}$ activation and initial growth of cloud droplets at the cloud base. Model test runs including collision-coalescence showed that coagulation can indeed be neglected at the early stages of cloud evolution investigated in this study (relative deviations $\leq 1 \%$ ).

Particle growth rates were calculated according to the following equation (Pruppacher and Klett, 1997; Simmel and Wurzler, 2006):

$$
\frac{d m}{d t}=\frac{4 \pi r\left(s_{\infty}-s_{e q}\right)}{\left(\frac{L_{V}}{R_{V} T}-1\right) \frac{L_{V}}{K^{*} T}+\frac{R_{V} T}{e_{s, w}(T) D^{*}}}
$$

where $m$ is the particle mass, $t$ the simulation time, $L_{V}$ the latent heat of condensation $\left(2.50078 \times 10^{6} \mathrm{~J} \mathrm{~kg}^{-1}\right), R_{V}$ the gas constant for water vapor $\left(461.5 \mathrm{~J} \mathrm{~kg}^{-1} \mathrm{~K}^{-1}\right), K^{*}$ the modified thermal conductivity of air $\left(\mathrm{W} \mathrm{m}^{-1} \mathrm{~K}^{-1}\right), e_{s, w}$ the saturation water vapor pressure, $D^{*}$ the modified diffusion coefficient for water vapor in air $\left(\mathrm{m}^{2} \mathrm{~s}^{-1}\right), s_{\infty}$ the saturation ratio of the surrounding air and $s_{e q}$ the equilibrium water vapor saturation ratio at the particle/air interface. For more details and parameterizations of $K^{*}$ and $D^{*}$ see Simmel and Wurzler 2006.

Both aerosol particle and cloud droplet size and growth are described on a common spectral grid. The simulations presented here were carried out using 264 logarithmically equidistant bins between $1 \mathrm{~nm}$ and $3.5 \mathrm{~mm}$ and a time step of $d t=0.01 \mathrm{~s}$. The weighting coefficient for the redistribution of mass between the size bins after each time step was set to $a=0.6$ (Simmel and Wurzler, 2006). The prognostic parameters include liquid water mass and particle number for each size bin.

The input parameters required to initialize the simulations are: (1) the initial meteorological conditions (temperature, pressure, relative humidity); (2) the updraft velocity of the air parcel; (3) the dry aerosol particle number size distribution; and (4) a set of parameters characterizing the hygroscopicity of the particle material according to Köhler theory (effective hygroscopicity parameter, $\kappa$, or a combination of stoichiometric dissociation coefficient and osmotic coefficient, $v_{s} \Phi_{s}$; see Sect. 2.2).

All model simulations were initialized with a temperature of $285.20 \mathrm{~K}$, a pressure of $950 \mathrm{hPa}$, and a relative humidity of 95\% (Simmel and Wurzler, 2006). They were carried through with a constant vertical velocity $(w)$, and stopped upon reaching a liquid water content (LWC) of $0.8 \mathrm{~g} \mathrm{~kg}^{-1}$. In different runs the vertical velocity $(w)$, initial aerosol particle number concentration $\left(N_{C N}\right)$, size distribution, and hygroscopicity parameter were varied as detailed below.

The highest value of the water vapor supersaturations calculated in the course of each simulation $\left(S=\left(s_{\infty}-1\right) 100 \%\right)$ was reported as the maximum supersaturation $S_{\max }$ (for an exemplary profile of $S$ see Fig. 1). The cloud droplet number concentrations $\left(N_{C D}\right)$ and activated particle frac- tions $\left(N_{C D} / N_{C N}\right)$ reported below were determined from the model output at the end of the simulation. Particles were counted as cloud droplets when the diameter is equal or larger than the critical droplet diameter corresponding to the water vapor saturation ratio in the modeled air parcel $(s=1+S /(100 \%))$ of each parcel model run (Seinfeld and Pandis, 2006; $D_{\text {wet }, c}=\frac{2 A}{3 \ln s_{c}}$ with $A=\frac{4 \sigma_{\text {sol }} M_{w}}{R T \rho_{w}}$ using $s_{c}=s$; $D_{\text {wet }, c}$ is the critical droplet diameter, $s_{c}$ is the critical water vapor supersaturation ratio, $\sigma_{\mathrm{sol}}$ is the surface tension of solution droplet, $M_{w}$ is the molar mass of water and $\rho_{w}$ is the density of pure water). Under the model conditions investigated in this study (constant updraft, no entrainment, no coagulation), the results are the same when using the maximum value or the final value of supersaturation for the calculation

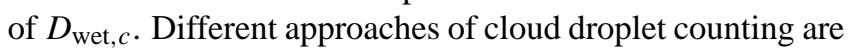
required and will be discussed in follow-up studies including coagulation, entrainment and variable updraft velocities.

\subsection{Köhler models}

According to Köhler theory (Köhler, 1936), the equilibrium water vapor saturation ratio $s_{e q}$ is given by

$s_{e q}=a_{w} \cdot K e$

where $a_{w}$ denotes the water activity or Raoult term, and $K e$ is the Kelvin term. In this study we have tested two different approaches of describing the influence of aerosol chemical composition and hygroscopicity on $a_{w}$ : an effective hygroscopicity parameter $(\kappa)$ Köhler model (Petters and Kreidenweis, 2007; Kreidenweis et al., 2009; Pöschl et al., 2009) and an osmotic coefficient (OS) reference model (Robinson and Stokes, 1959) which is more accurate but also more complex as detailed by Rose et al. (2008a). In the OS Köhler model, $a_{w}$ is given by

$a_{w}=\exp \left(-v_{s} \Phi_{s} \mu_{s} M_{w}\right)$

where $v_{s}, \Phi_{s}$ and $\mu_{s}$ are the stoichiometric dissociation number, osmotic coefficient and molality of the aerosol particle material (solute), respectively, and $M_{w}$ is the molar mass of water. In the test simulations for sodium chloride particles (Sect. 2.3), we have used $v_{s}=2$ and the parameterization of Pitzer and Mayorga (1973) for $\Phi_{s}$ (OS1 model of Rose et al., 2008a). In the $\kappa$-Köhler model $a_{w}$ is given by

$a_{w}=\frac{1}{1+\kappa \frac{V_{s}}{V_{w}}}$

where $\kappa$ is the effective hygroscopicity parameter or Raoult parameter, respectively (Petters and Kreidenweis, 2007; Mikhailov et al., 2009; Pschl et al., 2009). $V_{s}$ is the volume of dry particulate matter $\left(V_{s}=\frac{4}{3} \pi \cdot r_{s}^{3}\right.$, with $r_{s}$ the radius of the particles), and $V_{w}$ is the volume of water in the aqueous particle/droplet $\left(V_{w}=\frac{4}{3} \pi \cdot r_{w}^{3}\right.$, with $r_{w}$ the radius of the wet fraction). Characteristic values of $\kappa$ are 0 for completely insoluble particles, 0.6 for $\left(\mathrm{NH}_{4}\right)_{2} \mathrm{SO}_{4}$ and 1.28 for $\mathrm{NaCl}$ (Petters and Kreidenweis, 2007; Rose et al., 2008a). The hygroscopicity parameters of biomass burning aerosols range 

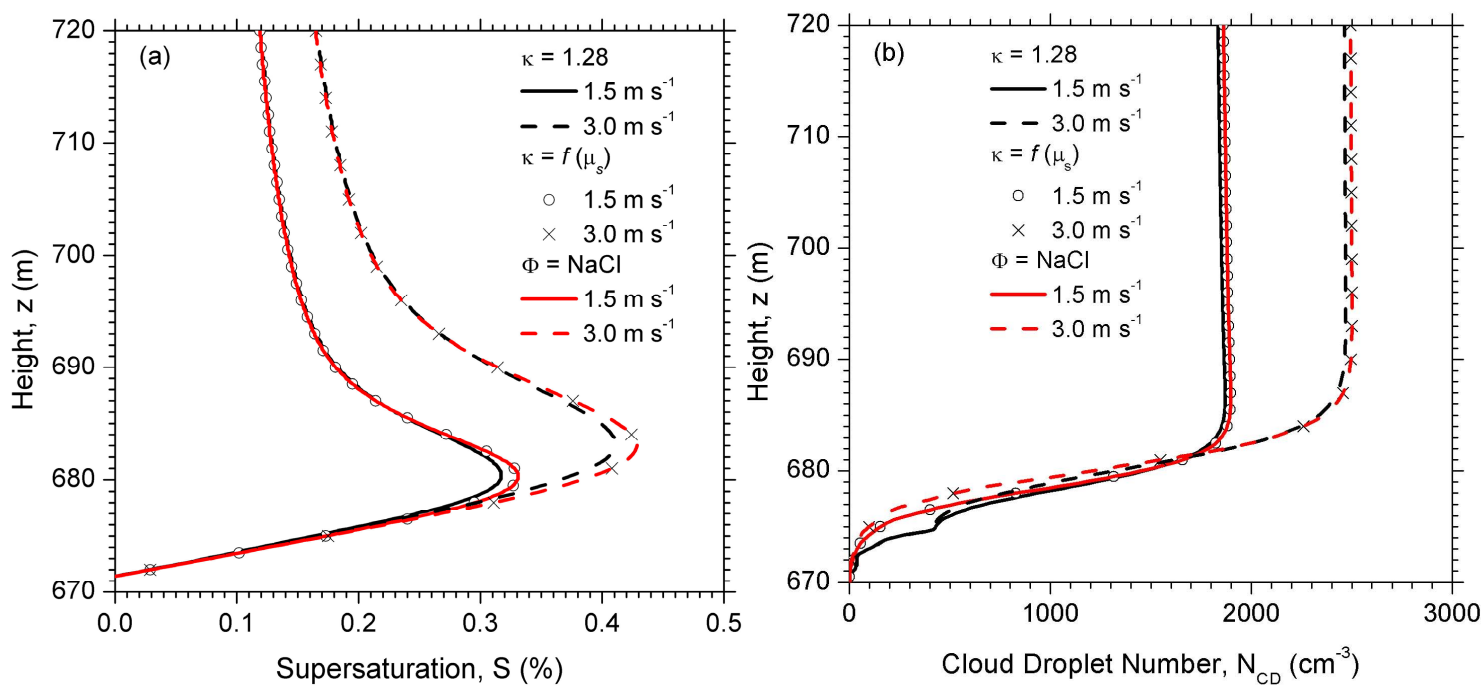

Fig. 1. Exemplary vertical profiles of (a) water vapor supersaturation $(S, \%)$ and (b) cloud droplet number concentration $\left(N_{C D}, \mathrm{~cm}^{-3}\right)$ simulated with different Köhler model approaches: osmotic coefficient model (red lines), $\kappa$-Köhler model with constant $\kappa$ (black lines) and $\kappa$-Köhler model with $\kappa$ dependent on solute molality, $\mu_{s}$ (open circles and crosses). The updraft velocity was set to $w=1.5 \mathrm{~m} \mathrm{~s}{ }^{-1}$ (solid lines or open circles) or $w=3.0 \mathrm{~m} \mathrm{~s}^{-1}$ (dashed lines or crosses), and the initial aerosol particle number concentration was set to $N_{C N}=3000 \mathrm{~cm}^{-3}$ with particle properties as specified by Segal and Khain (2006).

from 0.01 for freshly emitted smoke containing mostly soot particles (unpublished data from M. O. Andreae, 2007 and S. Kreidenweis, 2007) to 0.55 for aerosol from grass burning, and the average value of $\kappa$ in polluted continental air is $0.3 \pm 0.1$ (Andreae and Rosenfeld, 2008; Rose et al., 2008b; Pöschl et al., 2009).

In test simulations for sodium chloride particles (Sect. 2.3), we have used $\kappa=1.28$ and $\rho_{s}=2165 \mathrm{~kg} \mathrm{~m}^{-3}$ (EH1 model of Rose et al., 2008a). For the simulation of real atmospheric aerosols from biomass burning we have used $\kappa=0.2$ (Rose et al., 2008b) and $\rho_{s}=1300 \mathrm{~kg} \mathrm{~m}^{-3}$ The Kelvin term was described by

$K e=\exp \left(\frac{2 \sigma_{\mathrm{sol}}}{R_{V} T \rho_{w} r_{\mathrm{wet}}}\right)$

where $\sigma_{\text {sol }}$ and $r_{\text {wet }}$ are the surface tension and radius of the aqueous particle/droplet respectively. $R_{V}=461.5 \mathrm{~J} \mathrm{~kg}^{-1} \mathrm{~K}^{-1}$ and $\rho_{w}=1000 \mathrm{~kg} \mathrm{~m}^{-3}$ are the specific gas constant and density of water and $T$ is the temperature. In the test simulations for sodium chloride particles (Sect. 2.3) using the OS Köhler model and the $\kappa$-Köhler model, $\sigma_{\text {sol }}$ was calculated by a parameterization (Pruppacher and Klett, 1997). In other simulations using the $\kappa$-Köhler model, $\sigma_{\text {sol }}$ was set to $0.072 \mathrm{~J} \mathrm{~m}^{-2}$ (Petters and Kreidenweis, 2007).

\subsection{Model validation}

To validate the cloud parcel model after implementation of the $\kappa$-Köhler approach, we have compared it against simulations with the OS Köhler model and against the results of an alternative cloud parcel model using sodium chloride particles as a surrogate for atmospheric aerosols (Segal and Khain, 2006).

The influence of the different Köhler model approaches was evaluated in test simulations for two cloud base updraft velocities $\left(w=1.5 \mathrm{~m} \mathrm{~s}^{-1}\right.$ and $\left.3.0 \mathrm{~m} \mathrm{~s}^{-1}\right)$ with a total aerosol particle number concentration of $N_{C N}=3000 \mathrm{~cm}^{-3}$ and a log-normal size distribution as specified by Segal and Khain (2006) with a geometric mean diameter of $60 \mathrm{~nm}$ and a standard deviation of $\sigma_{g}=1.35$. Figure 1 shows that the maximum supersaturations $\left(S_{\max }\right)$ as well as the cloud droplet number concentrations $\left(N_{C D}\right)$ determined with the $\kappa$-Köhler model using $(\kappa=1.28)$ were slightly lower than with the OS reference model. The differences were caused by the different approaches of calculating water activity. To obtain equivalent water activities, i.e. $a_{w}(O S)=a_{w}(\kappa)$, we expressed $\kappa$ as a function of $\mu_{s}$ (Rose et al., 2008a).

$\kappa=f\left(\mu_{s}\right)=\left(\exp \left(v_{s} \Phi_{s} \mu_{s} M_{w}\right)-1\right) \frac{V_{w}}{V_{s}}$

Figure 2 illustrates the dependence of $\kappa$ on $\mu_{s}$ for sodiam chloride. Using $\kappa=f\left(\mu_{s}\right)$, the cloud parcel model produced the exact same results with the $\kappa$-Köhler model as with the OS reference model (Fig. 1), demonstrating the equivalence of the two model formulations. Additional tests with typical particle size distributions of urban aerosols ( $\mathrm{Su}$ et al., 2009) showed similar deviations in $S_{\max }$ and $N_{C D}$ for constant $\kappa=1.28$ and no deviations with $\kappa=f\left(\mu_{s}\right)$.

The validity of the cloud parcel model with the $\kappa$-Köhler approach was also confirmed by further model simulations with $N_{C N}=800-3600 \mathrm{~cm}^{-3}$ and $w=0.5-3.5 \mathrm{~m} \mathrm{~s}^{-1}$ with a $\kappa$ of 1.28 representing $\mathrm{NaCl}$. The resulting cloud droplet 


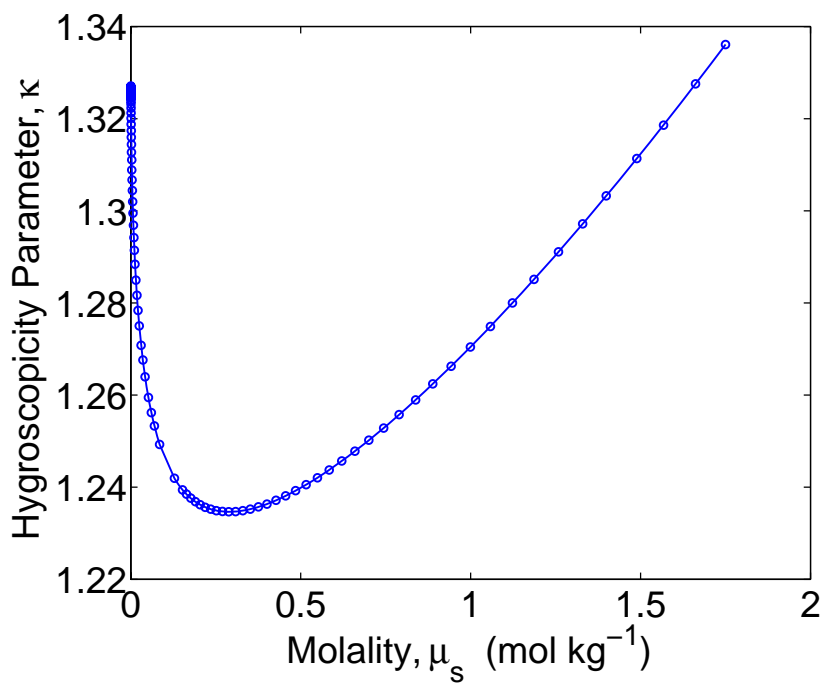

Fig. 2. Dependence of the effective hygroscopicity parameter $\kappa$ on solute molality for sodium chloride $\left(\kappa=f\left(\mu_{s}\right)\right.$, Sect. 2.3, Eq. 6.)

concentrations shown in Fig. 3 are in fair agreement with the results of Segal and Khain (2006, Fig. 6f) who investigated $\mathrm{CCN}$ activation with an alternative air parcel model with spectral description of warm cloud microphysics. At low $N_{C N}$, the cloud droplet number concentrations were up to $\sim 15 \%$ higher in our model, but at high $N_{C N}$ they were essentially the same as in Segal and Khain (2006, Fig. 6f).

\section{Results and discussion}

\subsection{Different regimes of $\mathrm{CCN}$ activation}

To probe and characterize the influence of aerosol particle number concentration and updraft velocity on CCN activation and droplet formation at the base of pyro-convective clouds, we have performed cloud parcel model simulations assuming a mono-modal particle size distribution characteristic for young biomass burning aerosols. The dry particle size distribution is determined by an accumulation mode with a count median or geometric mean diameter of $D_{g}=120 \mathrm{~nm}$, a geometric standard deviation of $\sigma_{g}=1.5$ (Reid et al., 2005; Janhäll et al., 2009), and the hygroscopic properties are described by an effective hygroscopicity parameter of 0.2 (Andreae and Rosenfeld, 2008; Rose et al., 2008b; Pöschl et al., 2009). The effects of variations in hygroscopicity will be addressed below (Sect. 3.2). In a series of 961 model runs the updraft velocity and the initial number concentration of aerosol particles have been varied systematically over the range of $w=0.25-20 \mathrm{~m} \mathrm{~s}^{-1}$ and $N_{C N}=0.2-100 \times 10^{3} \mathrm{~cm}^{-3}$.

Figure 4 shows the number concentration of cloud droplets, $N_{C D}$, that are formed at the cloud base as a function of $w$ and $N_{C N}$. Note, that $N_{C N}$ as used in this study effectively corresponds to $N_{C N, 30}$, i.e. the number of aerosol particles larger than $30 \mathrm{~nm}$. The corresponding activated frac-

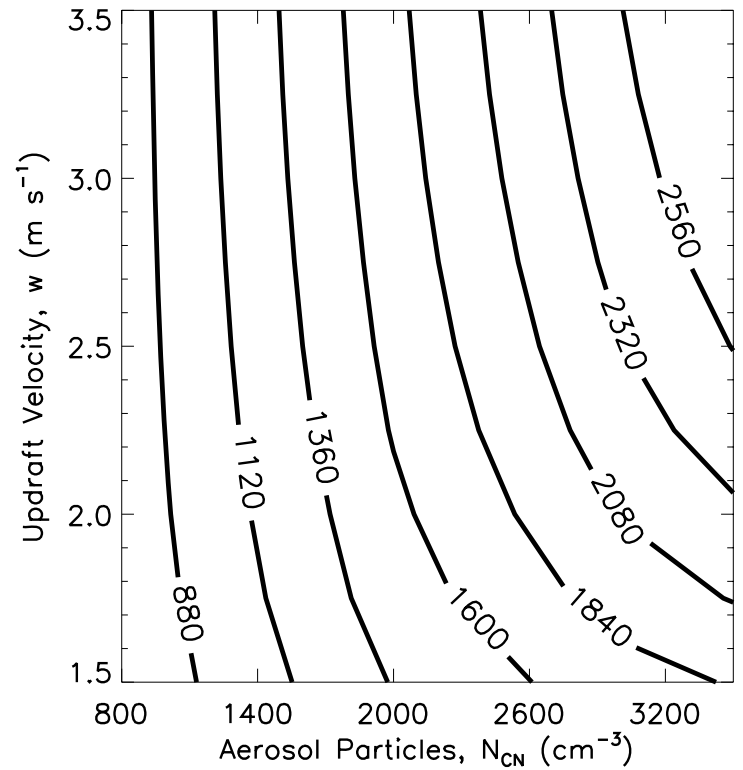

Fig. 3. Cloud droplet number concentrations $\left(N_{C D}, \mathrm{~cm}^{-3}\right.$; isolines) calculated as a function of updraft velocity $\left(w, \mathrm{~m} \mathrm{~s}^{-1}\right)$ and initial aerosol particle number concentration $\left(N_{C N}, \mathrm{~cm}^{-3}\right)$ with particle properties as specified by Segal and Khain (2006).

tions of aerosol particles and the maximum water vapor supersaturations reached in the ascending air masses $\left(S_{\max }\right)$ are shown in Figs. 5 and 6, respectively.

The $N_{C D}$ isolines (isopleths) shown in Fig. 4 exhibit three distinctly different regimes of $\mathrm{CCN}$ activation and cloud droplet formation: (1) an aerosol-limited regime in the upper left sector of the plot; (2) an updraft-limited regime in the lower right sector; and (3) an aerosol- and updraft-sensitive regime (transitional regime) along the diagonal from the lower left to the upper right corner (ridge of $N_{C D}$ isopleths). Note that the appearance of the cloud droplet isopleth plot is similar to that of the ozone isopleth plots which are widely used in atmospheric chemistry to distinguish and describe the so-called $\mathrm{NO}_{\mathrm{x}}$ - and VOC-limited regimes of ozone production and concentration (Seinfeld and Pandis, 2006, p. 236).

The aerosol-limited regime of $\mathrm{CCN}$ activation is characterized by a relatively high ratio between the updraft velocity and particle number concentration $\left(w / N_{C N}>\approx 10^{-3} \mathrm{~m} \mathrm{~s}^{-1} /\left(\mathrm{cm}^{-3}\right)\right.$, Fig. 4), by a high activated fraction of aerosol particles $\left(N_{C D} / N_{C N}>\approx 90 \%\right.$, Fig. 5), and by high maximum values of water vapor supersaturation $\left(S_{\max }>0.5 \%\right.$, Fig. 6). In this regime, $N_{C D}$ is directly proportional to $N_{C N}\left(\partial N_{C D} / \partial N_{C N} \approx 1\right)$ and practically independent of $w$ (isolines parallel to $\mathrm{y}$ axis; $\partial N_{C D} / \partial w \approx 0$ ). The high updraft velocities lead to maximum supersaturations large enough to activate nearly all aerosol particles except very small ones at the lower end of the size-distribution (critical dry diameter of CCN activation $<\approx 60 \mathrm{~nm}$ ). 

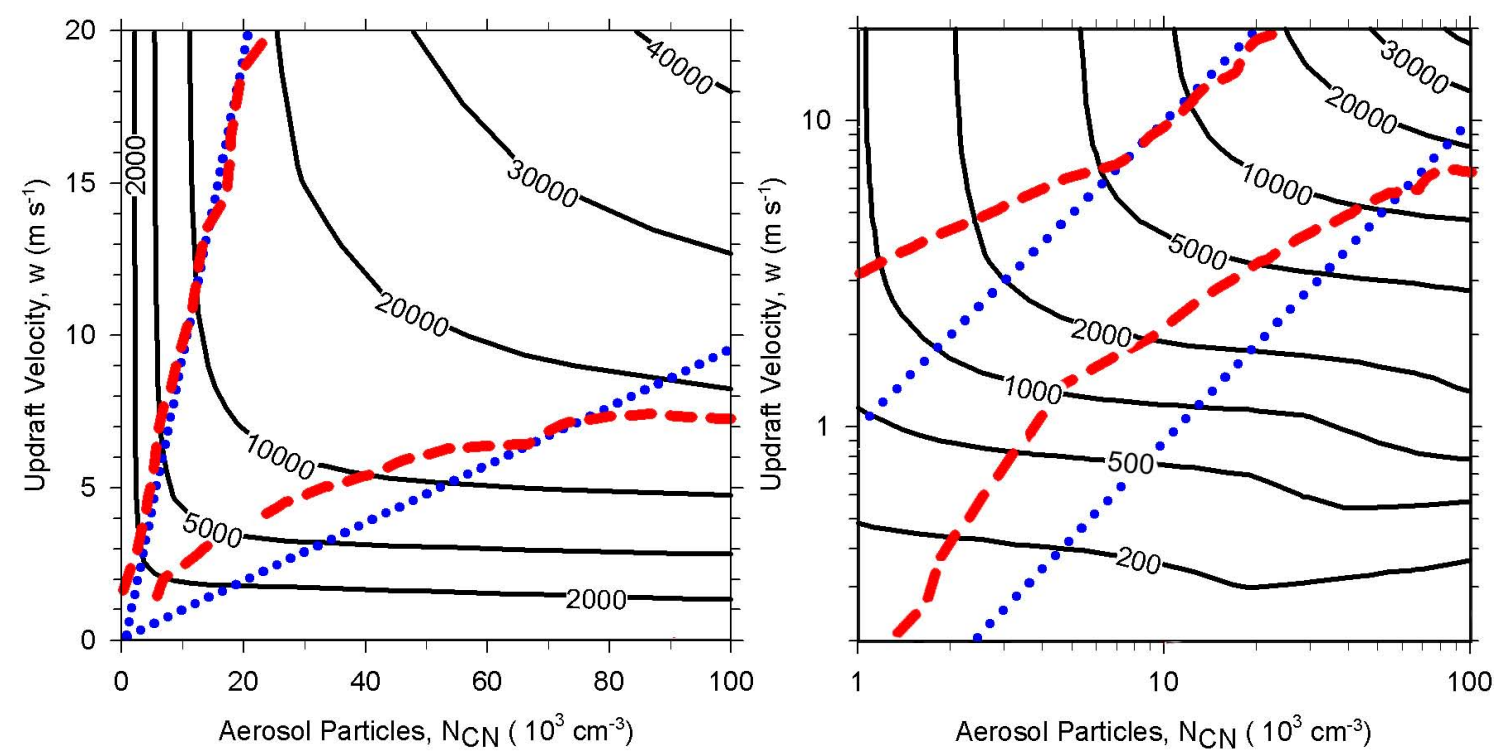

Fig. 4. Cloud droplet number concentrations $\left(N_{C D}, \mathrm{~cm}^{-3}\right.$; isolines) calculated as a function of updraft velocity $\left(w, \mathrm{~m} \mathrm{~s}^{-1}\right)$ and initial aerosol particle number concentration $\left(N_{C N}, \mathrm{~cm}^{-3}\right)$. (a) linear scale; (b) log-log scale. Red dashed lines indicate the borders between different regimes defined by $(\partial \ln \mathrm{NCD} / \partial \ln \mathrm{w}) /\left(\partial \ln N_{C D} / \partial \ln N_{C N}\right)=4$ or $1 / 4$, respectively. Blue dotted lines indicate approximate borders determined by $w / N_{C N}$.

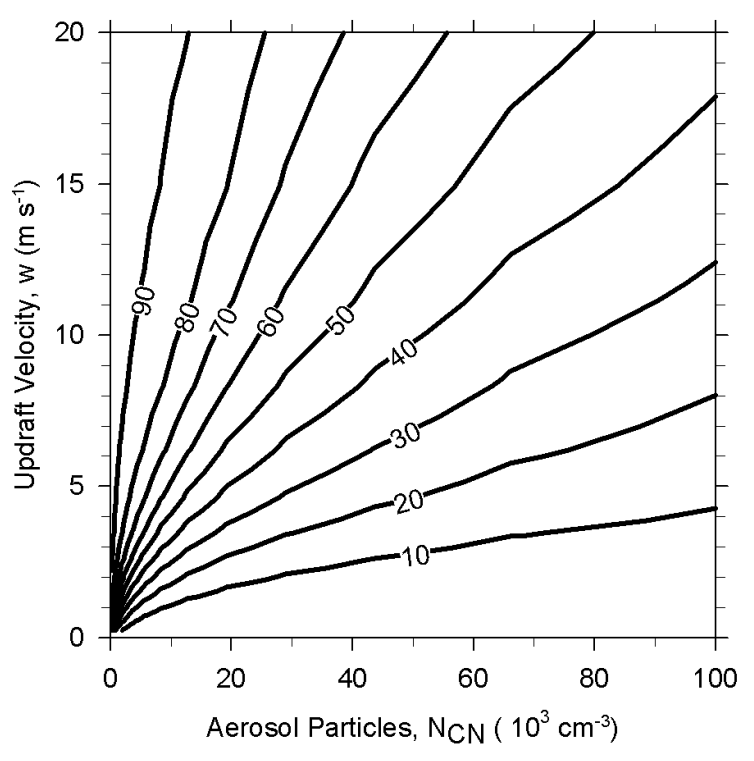

Fig. 5. Fraction of activated aerosol particles $\left(N_{C D} / N_{C N}\right.$, \%, isolines) calculated as a function of updraft velocity $\left(w, \mathrm{~m} \mathrm{~s}^{-1}\right)$ and initial aerosol particle number concentration $\left(N_{C N}, \mathrm{~cm}^{-3}\right)$.

The updraft-limited regime is characterized by a relatively low ratio between the updraft velocity and particle number concentration $\left(w / N_{C N}<\approx 10^{-4} \mathrm{~m} \mathrm{~s}^{-1} /\left(\mathrm{cm}^{-3}\right)\right.$, Fig. 4), by a low activated fraction of aerosol particles $\left(N_{C D} / N_{C N}<\approx 20 \%\right.$, Fig. 5), and by low maximum values of water vapor supersaturation $\left(S_{\max }<0.2 \%\right.$, Fig. 6). In this regime $N_{C D}$ exhibits a linear dependence on $w$ $\left(\partial N_{C D} / \partial w \approx 2 \times 10^{3} \mathrm{~cm}^{-3} /\left(\mathrm{m} \mathrm{s}^{-1}\right)\right)$ and a very weak dependence on $N_{C N}$ (small slope of isolines; $\partial N_{C D} / \partial N_{C N} \approx 0.02$ ). Due to the relatively low updraft velocities and high aerosol concentrations, the maximum supersaturations are so small that only large particles in the upper half of the size distribution are activated (critical dry diameter $>\approx 120 \mathrm{~nm}$ ). Under extremely low $w / N_{C N}$ conditions, water would be taken up by aerosol particles, the supersaturation would be quenched and $N_{C D}$ would drop to zero. E.g. for $w=0.1 \mathrm{~m} \mathrm{~s}^{-1}, N_{C D}$ would still be increased by adding more particles up to $N_{C N} \approx 1 \times 10^{5} \mathrm{~cm}^{-3}$, but would drop to zero at $N_{C N}>\approx 2 \times 10^{5} \mathrm{~cm}^{-3}$. This "supersaturation-quenched regime" where an increase in $\mathrm{N}_{C N}$ would lead to a reduction of $N_{C D}$, can be regarded as a special sub-regime of the updraft limited-regime of $\mathrm{CCN}$-activation. Note that a comparable sub-regime is also known in ozone chemistry: the $\mathrm{NO}_{\mathrm{x}}$ titration sub-regime in the VOCs-limited regime. In that subregime, increasing $\mathrm{NO}_{\mathrm{x}}$ leads to a decrease of ozone concentration. These similarities show the true color of nature beneath the complicated decoration, i.e., the similar principles underlying different physico-chemical processes in our environment.

The aerosol- and updraft-sensitive regime (transitional regime) is characterized by intermediate values of the ratio between the updraft velocity and particle number concentration $\left(w / N_{C N} \approx 0.5 \times 10^{-3} \mathrm{~m} \mathrm{~s}^{-1} \mathrm{~cm}^{3}\right.$, Fig. 4), of the activated fraction of aerosol particles $\left(N_{C D} / N_{C N} \approx 20-90 \%\right.$, Fig. 5), and of the maximum values of water vapor supersaturation $\left(S_{\max } \approx 0.2-0.5 \%\right.$, Fig. 6). In this regime $N_{C D}$ exhibits non-linear dependences on both $w$ and $N_{C N}$ (strong 
curvature of isolines; $\partial N_{C D} / \partial w \approx(0-2) \times 10^{3} \mathrm{~m} \mathrm{~s}^{-1} \mathrm{~cm}^{3}$; $\left.\partial N_{C D} / \partial N_{C N} \approx 0.4-1\right)$. Depending on the maximum supersaturations, the critical dry diameter for $\mathrm{CCN}$ activation ranges from well below up to the maximum of the aerosol particle size distribution $(\sim 60-120 \mathrm{~nm})$.

In the discussions above and based on Fig. $4 \mathrm{a}$, the borders between the three regimes were approximately defined by a constant $w / N_{C N}$ ratio. More generally and more accurately, the borders between the regimes can be defined by the relative sensitivities of $N_{C D}$ against changes in $w$ and $N_{C N}, \partial \ln N_{C D} / \partial \ln w \approx\left(\Delta N_{C D} / N_{C D}\right) /(\Delta w / w)$ and $\quad \partial \ln N_{C D} / \partial \ln N_{C N} \approx\left(\Delta N_{C D} / N_{C D}\right) /\left(\Delta N_{C N} / N_{C N}\right)$. From model results, the relative sensitivity ratio $R S=\left(\partial \ln N_{C D} / \partial \ln w\right) /\left(\partial \ln N_{C D} / \partial \ln N_{C N}\right) \quad$ can be calculated and used as a general parameter to quantitatively define and distinguish the different regimes of $\mathrm{CCN}$ activation.

For a wide range of pyro-convective conditions, the approximate borderlines $\left(w / N_{C N} \approx 10^{-3}\right.$ or $\left.10^{-4} \mathrm{~m} \mathrm{~s}^{-1} /\left(\mathrm{cm}^{-3}\right)\right)$ are in fair agreement with the borderlines determined by the general method using $R S=4$ or $1 / 4$, respectively (Fig. 4a). At low updraft velocities, however, the influence of $w$ is stronger than indicated by the approximate borderlines, i.e., the approximate borders of the transition regime deviated towards updraft limited regime (Fig. 4b).

In an earlier study, Twomey (1977) described the roles of updraft and aerosol number concentration by an analytical approximation of $N_{C D} \propto N_{\mathrm{CCN}, 1}^{2 /(\alpha+2)} w^{3 \alpha /(2 \alpha+4)}$ where $N_{\mathrm{CCN}, 1}$ is the cumulative $\mathrm{CCN}$ concentration at $1 \%$ supersaturation, $w$ is the updraft velocity and $\alpha$ is the slope of CCN supersaturation spectrum in the log-log scale. For a fixed size distribution, $N_{\mathrm{CCN}, 1}$ is proportional to $N_{C N}$ used in this study. According to the analytical approximation, the $N_{C D}$ isolines (isopleths) should be linear in a log-log plot. Thus we also plotted the $N_{C D}$ isolines on a log-log scale as shown in Fig. 4b. For either aerosol-limited or updraftlimited regimes, the isolines can be approximated by linear lines with different slope. However, over the whole range of $N_{\mathrm{CCN}, 1}$ and $w$, the isoline is obviously non-linear. This means the Twomey approximation with fixed $\alpha$ is not applicable over the whole investigated range of conditions.

The key features of the three regimes of $\mathrm{CCN}$ activation illustrated in Figs. 4-6 are not specific for young biomass burning aerosols and pyro-convective conditions but likely to apply also for other types of aerosols and meteorological conditions. This was confirmed by sensitivity studies with different aerosol size distributions $\left(D_{g}=60-200 \mathrm{~nm} ; \sigma_{g}=1.2-\right.$ 2.0). Moreover, Su et al. (2009) found the same type of regimes in their simulations based on particle size distributions and $\kappa$ values measured in polluted mega-city air of Beijing, and the same applies for pristine rainforest aerosols (Gunthe et al., 2009a) with different proportions of nucleation, Aitken, accumulation, and coarse mode particles. Un-

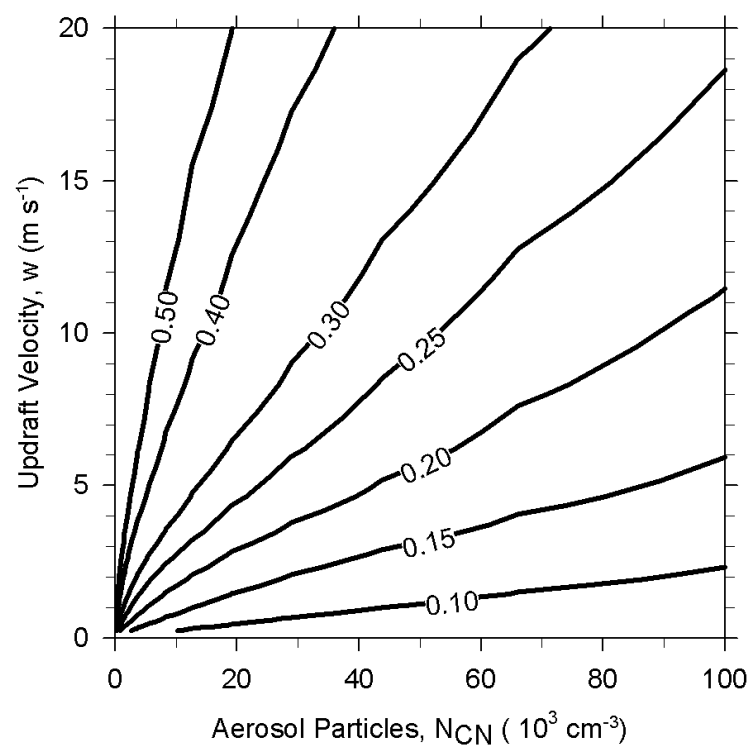

Fig. 6. Maximum supersaturation $\left(S_{\max }, \%\right.$, isolines) calculated as a function of updraft velocity $\left(w, \mathrm{~m} \mathrm{~s}^{-1}\right)$ and initial aerosol particle number concentration $\left(N_{C N}, \mathrm{~cm}^{-3}\right)$.

der these different conditions, the levels of isolines change but the shape stays the same. Just like in ozone chemistry, the existence of $\mathrm{NO}_{\mathrm{x}}$ - and VOCs-limited regimes can be generalized but the quantitative relations have to be adjusted to different conditions.

In the atmosphere, aerosol-limited conditions of $\mathrm{CCN}$ activation with high updraft velocities and low aerosol concentrations may occur in deep convection of clean air over tropical oceans and remote continental regions, as well as in thunderstorms in maritime air over land with strong vertical forcing of clean air masses (Murphey et al., 2005). Updraft-limited CCN activation with low updraft velocities and high aerosol concentrations is likely to occur in shallow convection of polluted air over locations or regions with strong sources of aerosols such as biomass burning and fossil fuel combustion in agricultural regions and mega-cities (Mönkkönen et al., 2005; Molina et al., 2007; Zhang et al., 2008; Rose et al., 2008; Wiedensohler et al., 2009). Aerosoland updraft-sensitive (transitional) conditions of CCN activation can occur in a wide range of regions and meteorological situations with low/moderate updraft velocities and aerosol concentrations (shallow convection in moderately polluted continental air), as well as in the high updraft velocities and aerosol concentrations typical for pyro-convection.

In comparison to our model results, the observed aerosolcloud droplet relations reported by Ramanathan et al. (2001a) would lie at the border between updraft-limited and transitional regimes of $\mathrm{CCN}$ activation (Fig. 7), corresponding to updraft velocities around $\sim 0.5 \mathrm{~m} \mathrm{~s}^{-1}$. Note, however, that the reported relations are characteristic for marine rather than pyro-convective conditions, which may limit the comparability. Model investigations using typical marine aerosol 
properties are under way and will be presented and discussed elsewhere (Gunthe et al., 2009b). Nevertheless, first results indicate that the regimes are not very different.

For pyro-convective clouds with $w \approx 5-20 \mathrm{~m} \mathrm{~s}^{-1}$ and $N_{C N} \approx 10^{4}-10^{5} \mathrm{~cm}^{-3}$, our model results indicate very high droplet number concentrations at the cloud base $\left(N_{C D} \approx(0.5-4) \times 10^{4} \mathrm{~cm}^{-3}\right.$; Fig. 4). The corresponding maximum water vapor supersaturations and activated fractions of aerosol particles are in the range of $0.2-0.5 \%$ and 20 $80 \%$, respectively (Figs. 5 and 6). The activated particle fractions are substantially higher than assumed in earlier model studies of pyro-convective clouds (5\%, Trentmann et al., 2006). However, the linear extrapolation of our results to extreme pyro-convective conditions $\left(N_{C N}=4 \times 10^{5} \mathrm{~cm}^{-3}\right.$, $w=20 \mathrm{~m} \mathrm{~s}^{-1}$ ) is consistent with the results of Chuang et al. (1992: $S_{\max }=0.15 \%, N_{C D} / N_{C N}=16 \%$ ).

When an aerosol particle is activated to a cloud droplet, the remaining fraction of the aerosol particles is transported as interstitial aerosol in the pyro-cloud. Unless they are scavenged by impaction with hydrometeors, they will be released into the atmosphere in the outflow region of the pyrocloud, which can be as high as the upper troposphere or the lower stratosphere (e.g., Fromm et al., 2005). To quantify the number of aerosol particles in the outflow region of pyroclouds, full three-dimensional simulations of pyro-clouds are required that take into account the interaction of aerosol particles and hydrometeors. Combining pyro-convective modeling activities (e.g., Trentmann et al., 2006; Luderer et al., 2007 ) with the investigation of aerosol-cloud interactions in convective clouds (e.g., Ekman et al., 2008) should help to better quantify the amount of aerosol deposited in the UT/LS region by pyro-convection.

\subsection{Aerosol particle hygroscopicity and size distribution}

To probe and characterize the influence of aerosol particle hygroscopicity and size distribution on $\mathrm{CCN}$ activation at the base of pyro-convective clouds, we have performed additional cloud parcel simulations for exemplary points in the three different regimes of CCN activation (aerosol-limited; updraft-limited; transitional; Fig. 4). In Sect. 3.2.1 we address the relative importance of the particle size distribution and hygroscopicity. In Sect. 3.2.2 we investigate and discuss hygroscopicity effects in more detail.

\subsubsection{Relative sensitivities}

Based on cloud parcel model simulations, Feingold (2003) proposed a linear regression method to calculate the relative sensitivity of one parameter (i.e. cloud-top effective radius) against the other parameters (variables). McFiggans et al. (2006) have also used this method to calculate the sensitivities of cloud droplet concentrations on other parameters, defining sensitivity $S\left(X_{i}\right)=\partial \ln N_{C D} / \partial \ln X_{i}$ where $X_{i}$ is the investigated parameter affecting $N_{C D}$, i.e., $N_{C N}, D_{g}, \sigma_{g}, w$

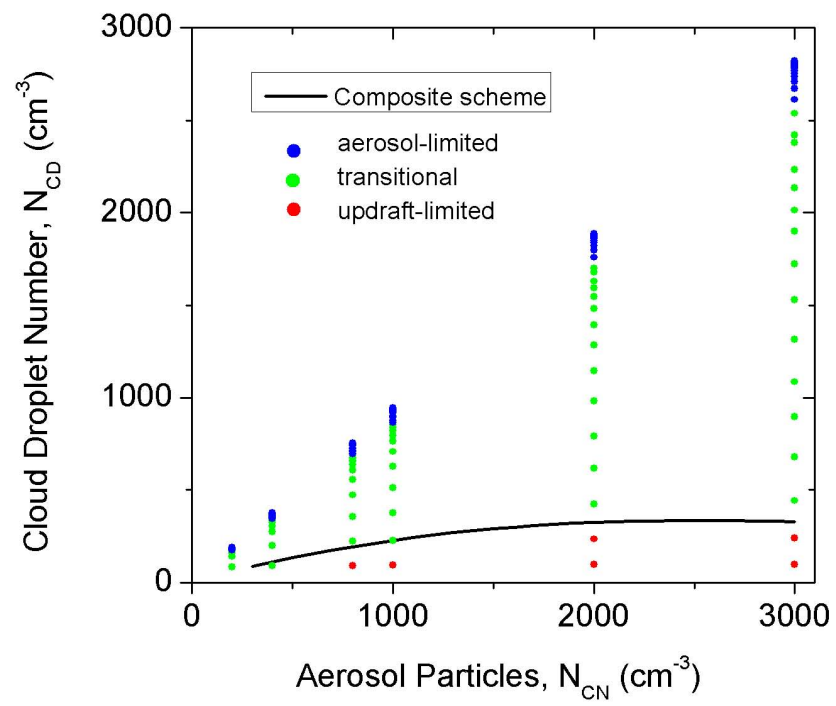

Fig. 7. The thick line labeled "Composite scheme" is obtained from a composite theoretical parameterization that fits the INDOEX aircraft data for the Arabian Sea (Ramanathan et al., 2001a, and equations for the line can be found in the Appendix A of Ramanathan et al., 2001b). The colored points are obtained from the same cloud parcel model simulations as shown in Fig. 4. The colors indicated the regimes determined by the $w / N_{C N}$ ratio.

or the mass fraction of ammonium sulphate $\varepsilon$ as a proxy of particle hygroscopicity. To calculate, for example, $S\left(N_{C N}\right)$ they plotted all values of $N_{C D}\left(N_{C N}, D_{g}, \sigma_{g}, w, \varepsilon\right)$, i.e., $N_{C D}$ calculated as a function of variable values of $N_{C N}, D_{g}$, $\sigma_{g}, w$ and $\varepsilon$ against $N_{C N}$ on a $\log -\log$ scale. Then a linear regression was appliedand the slope of the fit line was taken as $S\left(N_{C N}\right)$.

When this method was applied in the supersaturationquenched regime where $N_{C D}$ approaches zero (in case of very high $N_{C N}$ and/or $D_{g}$ values), $\ln N_{C D}$ values approaching $-\infty$ can strongly influence and distort the slope of the linear fit. To avoid this problem, we used modified method in which all values of $N_{C D}$ calculated at a given value of $X_{i}$ were averaged prior to fitting. Then the averaged values of $N_{C D}$ were plotted against $X_{i}$ on a log-log scale and linearly fitted. Since this method gives averaged values of relative sensitivities, we denote it with $\bar{S}\left(N_{C N}\right)$.

In the sensitivity studies, we used the same model setup and input parameters as detailed above (Sect. 3.1) to investigate three cases in different regimes, i.e. one in updraftlimited regime $\left(w=5 \mathrm{~m} \mathrm{~s}^{-1}, N_{C N}=8 \times 10^{4} \mathrm{~cm}^{-3}\right)$, one in aerosol-limited regime $\left(w=15 \mathrm{~m} \mathrm{~s}^{-1}, N_{C N}=1 \times 10^{4} \mathrm{~cm}^{-3}\right)$ and another one in the transitional regime $\left(w=10 \mathrm{~m} \mathrm{~s}^{-1}\right.$, $N_{C N}=5 \times 10^{4} \mathrm{~cm}^{-3}$ ). For each of the three investigated combinations of $w$ and $N_{C N}$ we varied the size distribution and hygroscopicity parameters as follows: $D_{g}=60-200 \mathrm{~nm}$, $\sigma_{g}=1.2-2.0$, and $\kappa=0.005-0.6$. 
Table 1. Average relative sensitivities of $N_{C D}$ on $X_{i}$, $\bar{S}\left(X_{i}\right)=\partial \ln \overline{N_{C D}} / \partial \ln X_{i}\left(\right.$ where $X_{i}$ is one of $D_{g}, \sigma_{g}$ and $\left.\kappa\right)$.

\begin{tabular}{lrrr}
\hline & $\begin{array}{r}\text { Aerosol- } \\
\text { limited regime } \\
\left(S_{\max }>0.5 \%\right)\end{array}$ & $\begin{array}{r}\text { Transitional regime } \\
\left(S_{\max }=0.2-0.5 \%\right)\end{array}$ & $\begin{array}{r}\text { Updraft- } \\
\text { limited regime } \\
\left(S_{\max }<0.2 \%\right)\end{array}$ \\
\hline$D_{g}$ & 0.39 & 0.45 & 0.32 \\
$\sigma_{g}$ & -0.50 & -0.91 & -0.92 \\
$\kappa$ & 0.15 & 0.17 & 0.13 \\
\hline
\end{tabular}

The three regimes are (a) aerosol-limited regime $\left(w=15 \mathrm{~m} \mathrm{~s}^{-1}\right.$ and $\left.N_{C N}=1 \times 10^{4} \mathrm{~cm}^{-3}\right)$; (b) transitional regime $\left(w=10 \mathrm{~m} \mathrm{~s}^{-1}\right.$ and $\left.N_{C N}=5 \times 10^{4} \mathrm{~cm}^{-3}\right)$; (c) updraft-limited regime $\left(w=5 \mathrm{~m} \mathrm{~s}^{-1}\right.$ and $\left.N_{C N}=8 \times 10^{4} \mathrm{~cm}^{-3}\right)$. The ranges of $X_{i}$ are $D_{g}=60-200 \mathrm{~nm}$, $\sigma_{g}=1.2-2.0$ and hygroscopicity parameter $\kappa=0.005-0.6$.

As shown in Table $1, \bar{S}\left(X_{i}\right)$ is positive for $D_{g}$ and $\kappa$ in all the regimes. This is because larger particles or more hygroscopic particles have a lower critical supersaturation. Across all regimes of $\mathrm{CCN}$ activation, the sensitivity of $N_{C D}$ against particle size, $\bar{S}\left(D_{g}\right)$, is two to three times higher than the sensitivity against chemical composition, $\bar{S}(\kappa)$. This is consistent with the relative sensitivity of $s_{c}$ on $D_{g}$ and $\kappa$, in which $\left(\partial \ln s_{c} / \partial D_{g}\right) /\left(\partial \ln s_{c} / \partial \kappa\right)=3$.

The sign of $\bar{S}\left(\sigma_{g}\right)$ is negative because the tail of the distribution at large sizes results in activation of larger droplets, reducing supersaturation and $N_{C D}$ values. For both $\bar{S}\left(D_{g}\right)$ and $\bar{S}(\kappa)$ the deviations between the aerosol-limited, transitional and updraft limited scenarios agreed to within $\pm 15 \%$. In contrast, $\bar{S}\left(\sigma_{g}\right)$ in the aerosol-limited scenario was by a factor of 1.8 lower than in the transitional and updraft-limited scenarios. The sensitivities determined in our case study for the aerosol limited regime are very similar to the values reported by McFiggans et al. 2006 for their polluted case $\left(3000 \mathrm{~cm}^{-3}>N_{C N}>1000 \mathrm{~cm}^{-3}\right)$.

As $N_{C D}$ is a function of five parameters $\left(N_{C N}, w, D_{g}, \sigma_{g}\right.$ and $\kappa), S\left(X_{i}\right)=\partial \ln N_{C D} / \partial \ln X_{i}$ can also be influenced by each of the parameters. As mentioned above, the sensitivities calculated in this section represent just an average sensitivity estimate. In the following section we explore how the relatively low average sensitivity against $\kappa$ varies under different conditions.

\subsubsection{Hygroscopicity effects}

We studied the chemical effects on $N_{C D}$, i.e. $S(\kappa)$, in different aerosol chemical composition conditions (different $\kappa$ conditions) for the three regimes. The same model setup and input parameters are used as detailed above (Sect. 3.1) and only $\kappa$ was varied from 0.005 to 0.6 , covering the full range of effective hygroscopicity parameters reported for $\mathrm{CCN}$ in continental air (Sect. 2.2, Andreae and Rosenfeld, 2008 and references therein).
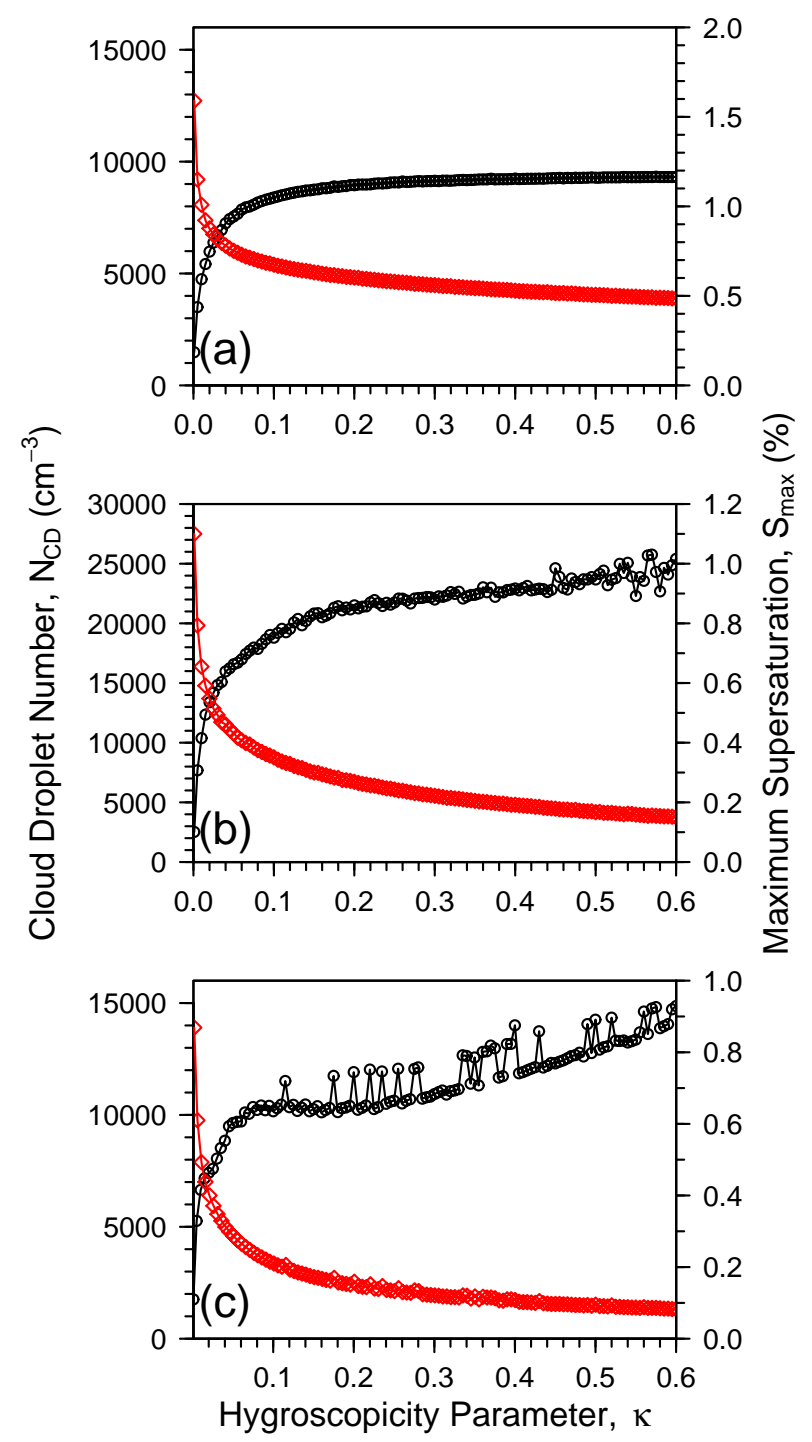

Fig. 8. Dependence of cloud droplet number concentrations $\left(N_{C D}, \mathrm{~cm}^{-3}\right.$, black) and maximum supersaturations $\left(S_{\max }\right.$, $\%$, red) on aerosol particle hygroscopicity $(\kappa=0.005-0.6)$ : (a) aerosol-limited regime $\left(w=15 \mathrm{~m} \mathrm{~s}^{-1}\right.$ and $\left.N_{C N}=1 \times 10^{4} \mathrm{~cm}^{-3}\right)$; (b) aerosol- and updraft-sensitive (transitional) regime $\left(w=10 \mathrm{~m} \mathrm{~s}^{-1}\right.$ and $\left.N_{C N}=5 \times 10^{4} \mathrm{~cm}^{-3}\right)$; (c) updraft-limited regime $\left(w=5 \mathrm{~m} \mathrm{~s}^{-1}\right.$ and $N_{C N}=8 \times 10^{4} \mathrm{~cm}^{-3}$ ).

Figure 8a shows the model results of $N_{C D}$ and $S_{\max }$ for exemplary conditions in the aerosol-limited regime $\left(w=15 \mathrm{~m} \mathrm{~s}^{-1}, N_{C N}=1 \times 10^{4} \mathrm{~cm}^{-3}\right)$. Under these conditions and for aerosol particles of medium or high hygroscopicity $(\kappa \geq 0.2)$, the cloud droplet number concentration is practically independent of $\kappa$ (plateau level in Fig. 8a). The relative sensitivities $S(\kappa)=\partial \ln N_{C D} / \partial \ln \kappa \approx\left(\Delta N_{C D} / N_{C D}\right) /(\Delta \kappa / \kappa)$ is $\leq 0.06$, i.e., a $\sim 50 \%$ difference in $\kappa$ would change $N_{C D}$ by less than $3 \%$ (Table 2). For aerosol particles with low hygroscopicity $(0.05<\kappa<0.2)$, the dependence of $N_{C D}$ on $\kappa$ is still modest, with relative sensitivities $S(\kappa)$ in the range of 
Table 2. Relative sensitivities of the cloud droplet concentration $N_{C D}$ on the hygroscopicity parameter $\kappa, S(\kappa)=\partial \ln N_{C D} / \partial \ln \kappa \approx$ $\left(\Delta N_{C D} / N_{C D}\right) /(\Delta \kappa / \kappa)$ in the aerosol-limited, transitional and updraft-limited regimes of CCN activation. Numerical values correspond to the exemplary scenarios illustrated in Fig. 8.

\begin{tabular}{lcccccc}
\hline$\kappa$ & $\begin{array}{c}\text { Aerosol-limited regime } \\
\left(S_{\max }>0.5 \%\right)\end{array}$ & $\begin{array}{c}\text { Transitional regime } \\
\left(S_{\max }=0.2-0.5 \%\right)\end{array}$ & $\begin{array}{c}\text { Updraft-limited regime } \\
\left(S_{\max }<0.2 \%\right)\end{array}$ \\
& $\mathrm{N}_{C D}, 10^{3} \mathrm{~cm}^{-3}$ & $S(\kappa)$ & $\mathrm{N}_{C D}, 10^{3} \mathrm{~cm}^{-3}$ & $S(\kappa)$ & $\mathrm{N}_{C D}, 10^{3} \mathrm{~cm}^{-3}$ & $S(\kappa)$ \\
\hline 0.025 & 6.0 & 0.50 & 14.0 & 0.50 & 8.0 & 0.50 \\
0.05 & 7.5 & 0.23 & 16.5 & 0.22 & 9.6 & 0.10 \\
0.1 & 8.4 & 0.12 & 19.0 & 0.21 & 10.2 & 0.06 \\
0.2 & 8.9 & 0.06 & 21.0 & 0.10 & 10.5 & 0.10 \\
0.3 & 9.1 & 0.03 & 22.0 & 0.08 & 11.0 & 0.22 \\
0.4 & 9.2 & 0.02 & 23.0 & 0.11 & 13.0 & 0.30 \\
0.5 & 9.3 & 0.02 & 24.0 & 0.14 & 13.3 & 0.41 \\
\hline
\end{tabular}

$0.06-0.2$. Only for particles with very low hygroscopicity $(\kappa<0.05), N_{C D}$ depends strongly on $\kappa$. The relative sensitivities $S(\kappa)$ are $\geq 0.2$, i.e., a $\sim 50 \%$ difference in $\kappa$ would change $N_{C D}$ by more than $10 \%$ (Table 2).

Figure $8 \mathrm{~b}$ shows the model results for exemplary conditions in the transitional regime $\left(w=10 \mathrm{~m} \mathrm{~s}^{-1}\right.$, $N_{C N}=5 \times 10^{4} \mathrm{~cm}^{-3}$ ). The dependence of $N_{C D}$ on $\kappa$ is qualitatively similar to the aerosol-limited regime (Fig. 8a), but the relative sensitivities $S(\kappa)$ are larger, i.e., differences in $\kappa$ result in larger differences in $N_{C D}$ and (Table 2). Note that at $\kappa>0.4$ the maximum supersaturation dropped below $0.2 \%$, indicating a changeover into the updraft limited regime. At $\kappa>0.45$ strong wiggles/outliers in the curve of $N_{C D}$ vs. $\kappa$ indicate that the model resolution becomes a limiting factor under these conditions (low $S$, high $N_{C N}$ ).

Figure $8 \mathrm{c}$ shows the model results for exemplary conditions in the updraft-limited regime $\left(w=5 \mathrm{~m} \mathrm{~s}^{-1}\right.$, $N_{C N}=8 \times 10^{4} \mathrm{~cm}^{-3}$ ). Again the dependence of $N_{C D}$ on $\kappa$ is qualitatively similar to the aerosol-limited regime (Fig. 8a), but the relative sensitivities $S(\kappa)$ are smaller for particles with low hygroscopicity $(0.05<\kappa<0.2)$ and larger for particles with medium or high hygroscopicity $(\kappa \geq 0.2$, Table 2$)$. Note, however, that at $\kappa \approx 0.12$ the maximum supersaturations drop already below $0.2 \%$ and strong wiggles/outliers in the curve of $N_{C D}$ vs. $\kappa$ indicate that the model resolution becomes a limiting factor.

Overall, the results summarized in Table 2 and Fig. 8 show that within the range of effective hygroscopicity parameters that is characteristic for continental atmospheric aerosols $(\kappa \approx 0.05-0.6), N_{C D}$ does not strongly depend on the actual value of $\kappa$. As $\kappa$ increases, $S_{\max }$ decreases which effectively leads to a buffering of $N_{C D}$ (self-regulation as discussed by Feingold and Siebert, 2009). Only for aerosols with very low average hygroscopicity ( $\kappa<0.05$, all regimes) and in the updraft-limited regime also for aerosols with higher than average hygroscopicity $\left(\kappa>0.3, S_{\max }<0.2 \%\right)$ did the relative sensitivities $S(\kappa)$ exceed values of $\sim 0.2$, indicating that a $50 \%$ difference in $\kappa$ would change $N_{C D}$ by more than $10 \%$. At $\kappa<0.03$ and in the updraft-limited regime at $\kappa>0.5$ $\left(S_{\max } \leq 0.1 \%\right)$ the relative sensitivities $S(\kappa)$ exceeded values of $\sim 0.4$, indicating that a $50 \%$ difference in $\kappa$ would change $N_{C D}$ by more than $20 \%$. These findings are consistent with earlier studies investigating the influence of aerosol chemical composition on $\mathrm{CCN}$ activation in cloud parcel models (e.g., Lance et al., 2004; Rissman et al., 2004; Ervens et al., 2005; Feingold and Siebert, 2009).

In another set of model simulations we added a coarse particle mode with $D_{g, c}=5 \mu \mathrm{m}$ and $\sigma_{g, c}=1.3$, and we assigned different fractions of $N_{C N}$ to this mode $\left(f_{N, c}=10^{-5}\right.$ to $10^{-3}$; Reid et al., 2005; Liu et al., 2008; Janhäll et al., 2009). With $f_{N, c}=10^{-5}$ and in the aerosol-limited regime, the coarse particle mode had practically no influence on $N_{C D}$ $\left(\Delta N_{C D} / N_{C D} \approx 0\right)$. In the transitional regime $\Delta N_{C D} / N_{C D}$ increased with decreasing $S_{\max }$ up to $\sim 10 \%$ for $f_{N, c}=10^{-4}$ and $\sim 30 \%$ for $f_{N, c}=10^{-3}$, respectively. At $S_{\max }<0.1 \%$ in the updraft-limited regime $\Delta N_{C D} / N_{C D}$ exceeded $\sim 20 \%$ for $f_{N, c}=10^{-4}$ and $\sim 70 \%$ for $f_{N, c}=10^{-3}$, respectively.

Overall, the sensitivity studies show that the calculated relative changes in $N_{C D}$ exceeded more than $20 \%$ only in the updraft limited regime. Since pyro-convective clouds are mostly outside the updraft-limited regime and because our model setup sensitive to small changes at very low supersaturations, we did not further investigate the influence of coarse mode particles on $\mathrm{CCN}$ activation in the updraft limited regime. Nevertheless, we suggest and intend to investigate this aspect further with model studies and observational data for polluted mega-city regions, which are often in the updraft limited regime. For this purpose, we also suggest and intend to apply models that enable assigning different hygroscopic properties to accumulation, Aitken and coarse mode particles (Gunthe et al., 2009a; Rose et al., 2008b; Wiedensohler et al., 2009). Moreover, potential kinetic limitations of water vapor uptake at the interface and into the bulk of aerosol particles have not been considered in the present 
study but need to be further explored and clarified (Nenes et al., 2001; Laaksonen et al., 2005; McFiggans et al., 2006; Pöschl et al., 2007, 2009; Engelhart et al., 2008; Ruehl et al., 2008; Asa-Awuku et al., 2009; Mikhailov et al., 2009; and references therein).

\section{Conclusions}

Based on cloud parcel model simulations, we found that $\mathrm{CCN}$ activation and cloud droplet formation can be classified into three regimes roughly depending on the ratio between updraft velocity and particle number concentration $\left(w / N_{C N}\right)$ : (1) an aerosol-limited regime (high $\left.w / N_{C N}\right),(2)$ an updraft-limited regime (low $w / N_{C N}$ ) and (3) a transitional regime (intermediate $\left.w / N_{C N}\right)$. The relative sensitivity ratio $R S=\left(\partial \ln N_{C D} / \partial \ln w\right) /\left(\partial \ln N_{C D} / \partial \ln N_{C N}\right)$ of $4: 1$ and $1: 4$ can used as a general parameter to quantitatively define and distinguish the different regimes of $\mathrm{CCN}$ activation.

Overall, the model results suggest that the variability of initial cloud droplet number concentration in convective clouds is mostly dominated by the variability of updraft velocity and aerosol particle number concentration in the accumulation mode. Coarse mode particles and the variability of particle composition expressed through the hygroscopicity parameter $\kappa$ appear to play important roles only at very low supersaturation in the updraft-limited regime of CCN activation (in particular at $S \leq 0.1 \%$ ).

These conclusions are consistent with field measurements demonstrating that $\mathrm{CCN}$ number concentrations in pristine as well as in highly polluted continental air can be efficiently predicted with a constant average hygroscopicity parameter, whereby the relative deviations between modeled and measured CCN concentrations exceeded $50 \%$ only at very low supersaturations $(\leq 0.1 \%$; Rose et al., 2008b; Gunthe et al., 2009a). Thus, we suggest that further experimental and theoretical studies of $\mathrm{CCN}$ activation and cloud droplet formation should be focused primarily on the updraft-limited regime, low water vapor supersaturations and potential kinetic limitations of $\mathrm{CCN}$ activation.

Acknowledgements. This work has been supported by an International Max Planck Research School fellowship and by the the European integrated project on aerosol cloud climate and air quality interactions (No 036833-2, EUCAARI). We thank A. Seifert, M. Lawrence, S. Janhäll and D. Rosenfeld for helpful discussions.

The service charges for this open access publication have been covered by the Max Planck Society.

Edited by: V.-M. Kerminen

\section{References}

Altaratz, O., Koren, I., Reisin, T., Kostinski, A., Feingold, G., Levin, Z., and Yin, Y.: Aerosols' influence on the interplay between condensation, evaporation and rain in warm cumulus cloud, Atmos. Chem. Phys., 8, 15-24, 2008, http://www.atmos-chem-phys.net/8/15/2008/.

Andreae, M. O., Artaxo, P., Fischer, H., Freitas, S. R., Gregoire, J.-M., Hansel, A., Hoor, P., Kormann, R., Krejci, R., Lange, L., Lelieveld, J., Lindinger, W., Longo, K., Peters, W., de Reus, M., Scheeren, B., Silva Dias, M. A. F., Ström, J., van Velthofen, P. F. J., and Williams, J.: Transport of biomass burning smoke to the upper troposphere by deep convection in the equatorial region, Geophys. Res. Lett., 28, 951-954, 2001.

Andreae, M. O., Rosenfeld, D., Artaxo, P., Costa, A. A., Frank, G. P., Longo, K. M., and Silva-Dias, M. A. F.: Smoking Rain Clouds over the Amazon, Science, 303, 1337-1342, 2004.

Andreae, M. O. and Rosenfeld, D.: Aerosol-cloudprecipitation interactions. Part 1: The nature and sources of cloud-active aerosols, Earth Sci. Rev., 89, 13-41, doi:10.1016/j.earscirev.2008.03.001, 2008.

Asa-Awuku, A., Engelhart, G. J., Lee, B. H., Pandis, S. N., and Nenes, A.: Relating CCN activity, volatility, and droplet growth kinetics of -caryophyllene secondary organic aerosol, Atmos. Chem. Phys., 9, 795-812, 2009,

http://www.atmos-chem-phys.net/9/795/2009/.

Chuang, C. C., Penner, J. E., and Edwards, L. L.: Nucleation Scavenging of Smoke Particles and Simulated Drop Size Distributions over Large Biomass Fires, J. Atmos. Sci, 49(14), 1264-1275, 1992.

Cubison, M. J., Ervens, B., Feingold, G., Docherty, K. S., Ulbrich, I. M., Shields, L., Prather, K., Hering, S., and Jimenez, J. L.: The influence of chemical composition and mixing state of Los Angeles urban aerosol on CCN number and cloud properties, Atmos. Chem. Phys., 8, 5649-5667, 2008, http://www.atmos-chem-phys.net/8/5649/2008/.

Diehl, K., Simmel, M., and Wurzler, S.: Numerical sensitivity studies on the impact of aerosol properties and drop freezing modes on the glaciation, microphysics, and dynamics of clouds, J. Geophys. Res., 111, D07202, doi:10.1029/2005JD005884, 2006.

Diehl, K., Simmel, M., and Wurzler, S.: Effects of drop freezing on microphysics of an ascending cloud parcel under biomass burning conditions, Atmos. Environ., 41, 303-314, 2007.

Ekman, A. M. L., Krejci, R., Engstrom, A., Ström, J., de Reus, M., Williams, J., and Andreae, M. O.: Do organics contribute to small particle formation in the Amazonian upper troposphere?, Geophys. Res. Lett., 35, L17810, doi:10.1029/2008GL034970, 2008.

Ervens, B., Feingold, G., and Kreidenweis, S. M.: The influence of water soluble organic carbon on cloud drop number concentration, J. Geophys. Res., 110, D18211, doi:10.1029/2004JD005634, 2005.

Engelhart, G. J., Asa-Awuku, A., Nenes, A., and Pandis, S. N.: $\mathrm{CCN}$ activity and droplet growth kinetics of fresh and aged monoterpene secondary organic aerosol, Atmos. Chem. Phys., 8, 3937-3949, 2008, http://www.atmos-chem-phys.net/8/3937/2008/.

Feingold, G.: Modeling of the first indirect effect: Analysis of measurement requirements, Geophys. Res. Lett., 19, p. 1997, doi:10.1029/2003GL017967, 2003. 
Feingold, G. and Siebert, H.: Cloud-aerosol interactions from the micro to cloud scale, edited by: Heintzenberg, J. and Charlson, R. J., MIT Press, Cambridge, 319-338, 2009.

Fromm, M., Alfred, J., Hoppel, K., Hornstein, J., Bevilacqua, R., Shettle, E., Servranckx, R., Li, Z., and Stocks., B.: Observations of boreal forest fire smoke in the stratosphere by POAM III, SAGE II, and lidar in 1998, Geophys. Res. Lett., 27(9), 14071410, 2000.

Fromm, M. and Servranckx, R.: Transport of forest fire smoke above the tropopause by supercell convection, Geophys. Res. Lett., 30(10), 1542, doi:10.1029/2002GL016820, 2003.

Fromm, M., Bevilacqua, R., Servranckx, R., Rosen, J., Thayer, J. P., Herman, J., and Larko, D.: Pyro-cumulonimbus injection of smoke to the stratosphere: Observations and impact of a super blowup in northwestern Canada on 3-4 August 1998, J. Geophys. Res., 110, D08205, doi:10.1029/2004JD005350, 2005.

Gunthe, S. S., King, S. M., Rose, D., Chen, Q., Roldin, P., Farmer, D. K., Jimenez, J. L., Artaxo, P., Andreae, M. O., Martin, S. T., and Pöschl, U.: Cloud condensation nuclei in pristine tropical rainforest air of Amazonia: size-resolved measurements and modeling of atmospheric aerosol composition and CCN activity, Atmos. Chem. Phys. Discuss., 9, 3811-3870, 2009a, http://www.atmos-chem-phys-discuss.net/9/3811/2009/.

Gunthe, S., Su, H., Pöschl, U., et al.: Aerosol- and updraft-limited regimes of CCN activation over blue and green oceans, in preparation, $2009 \mathrm{~b}$.

Hegg, D. A.: Dependence of Marine Stratocumulus Formation on Aerosols, Geophys. Res. Lett., 26(10), 1429-1432, 1999.

Helsper, C., Fissan, H. J., Muggli, J., and Scheidweiler, A.: Particle number distribution of aerosols from test fires, J. Atmos. Sci., 11, 439-446, 1980.

Hjelmfelt, M. R., Farley, R. D., and Chen, P. C. S.: A preliminary numerical study into the effects of coal development on cloud and precipitation processes in the Northern Great Plains, J. Appl. Meteorol., 17(6), 846-857, 1978.

IAPSAG: WMO/IUGG International Aerosol Precipitation Science Assessment Group (IAPSAG) Report: Aerosol Pollution Impact on Precipitation: A Scientific Review, Geneva, World Meteorological Organization, 482 pp., 2007.

IPCC: Climate Change 2007: The Physical Science Basis. Contribution of Working Group I to the Fourth Assessment Report of the Intergovernmental Panel on Climate Change, edited by: Solomon, S., Qin, D., Manning, M., Chen, Z., Marquis, M., Averyt, K., Tignor, M., and Miller, H. L., Cambridge University Press, Cambridge and New York, 996 pp., 2007.

Janhäll, S., Andreae, M. O., and Pöschl, U.: Biomass burning aerosol emissions from vegetation fires: particle number and mass emission factors and size distributions, Atmos. Chem. Phys. Discuss., 9, 17183-17217, 2009,

http://www.atmos-chem-phys-discuss.net/9/17183/2009/.

Jiang, H. J., Wang, B., Goya, K., Hocke, K., Eckermann, S. D., Ma, J., Wu, D. L., and Read W. G.: Geographical distribution and interseasonal variability of tropical deep convection: UARS MLS observations and analyses, J. Geophys. Res., 109, D03111, doi:10.1029/2003JD003756, 2004.

Kivekas, N., Kerminen, V. M., Anttila, T., Korhonen, H., Lihavainen, H., Komppula, M., and Kulmala, M.: Parameterization of cloud droplet activation using a simplified treatment of the aerosol number size distribution, J. Geophys Res., 113(D15),
D15207, doi:10.1029/2007JD009485, 2008.

Khain, A. P., BenMoshe, N., and Pokrovsky, A.: Factors determining the impact of aerosols on surface precipitation from clouds: An attempt at classification, J. Atmos. Sci., 65, 1721-1748, 2008.

Kreidenweis, S. M., Petters, M. D., and Chuang, P. Y.: Cloud particle precursors, in: Clouds in the perturbed climate system - their relationship to energy balance, atmospheric dynamics, and precipitation, edited by: Heintzenberg, J. and Charlson, R. J., MIT Press, Cambridge, 291-317, 2009.

Köhler, H.: The nucleus in the growth of hygroscopic droplets, T. Faraday Soc., 32, 1152-1161, 1936.

Laaksonen, A., Vesala, T., Kulmala, M., Winkler, P. M., and Wagner, P. E.: Commentary on cloud modelling and the mass accommodation coefficient of water, Atmos. Chem. Phys., 5, 461-464, 2005 , http://www.atmos-chem-phys.net/5/461/2005/.

Lance, S., Nenes, A., and Rissman, T. A.: Chemical and dynamical effects on cloud droplet number: Implications for estimates of the aerosol indirect effect, J. Geophys. Res., 109(D22), D22208, doi:10.1029/2004JD004596, 2004.

Liu, S.,Hu, M., Wu, Z., Wehner, B., Wiedensohler, A., and Cheng, Y.: Aerosol number size distribution and new particle formation at a rural/coastal site in Pearl River Delta (PRD) of China, Atmos. Environ., 42, 6275-6283, 2008.

Lohmann, U., Broekhuizen, K., Leatich, R. Shantz, and Abbatt, J.: How efficient is cloud droplet formation of organic aerosols, Geophys. Res. Lett., 31, L05108, doi:10.1029/2003GL018999, 2004.

Luderer, G., Trentmann, J., Winterrath, T., Textor, C., Herzog, M., Graf, H. F., and Andreae, M. O.: Modeling of biomass smoke injection into the lower stratosphere by a large forest fire (Part II): sensitivity studies, Atmos. Chem. Phys., 6, 5261-5277, 2006, http://www.atmos-chem-phys.net/6/5261/2006/.

McFiggans, G., Artaxo, P., Baltensperger, U., Coe, H., Facchini, M. C., Feingold, G., Fuzzi, S., Gysel, M., Laaksonen, A., Lohmann, U., Mentel, T. F., Murphy, D. M., O’Dowd, C. D., Snider, J. R., and Weingartner, E.: The effect of physical and chemical aerosol properties on warm cloud droplet activation, Atmos. Chem. Phys., 6, 2593-2649, 2006,

http://www.atmos-chem-phys.net/6/2593/2006/.

Mikhailov, E., Vlasenko, S., Martin, S. T., Koop, T., and Pöschl, U.: Amorphous and crystalline aerosol particles interacting with water vapor - Part 1: Microstructure, phase transitions, hygroscopic growth and kinetic limitations, Atmos. Chem. Phys. Discuss., 9, 7333-7412, 2009,

http://www.atmos-chem-phys-discuss.net/9/7333/2009/.

Molina, L. T., Kolb, C. E., de Foy, B., Lamb, B. K., Brune, W. H., Jimenez, J. L., Ramos-Villegas, R., Sarmiento, J., ParamoFigueroa, V. H., Cardenas, B., Gutierrez-Avedoy, V., and Molina, M. J.: Air quality in North America's most populous city overview of the MCMA-2003 campaign, Atmos. Chem. Phys., 7, 2447-2473, 2007, http://www.atmos-chem-phys.net/7/2447/2007/.

Mönkkönen, P., Koponen, I. K., Lehtinen, K. E. J., Hämeri, K., Uma, R., and Kulmala, M.: Measurements in a highly polluted Asian mega city: observations of aerosol number size distribution, modal parameters and nucleation events, Atmos. Chem. Phys., 5, 57-66, 2005,

http://www.atmos-chem-phys.net/5/57/2005/. 
Murphey, H. V., Wakimoto, R. M., Flamant, C., and Kingsmill., D. E.: Dryline on 19 June 2002 during IHOP. Part I: Airborne Doppler and LEANDRE II Analyses of the Thin Line Structure and Convection Initiation, Mon. Weather Rev., 134, 406-430, 2006.

Nenes, A., Ghan, S., Abdul-Razzak, H., Chuang, P. Y., and Seinfeld, J. H.: Kinetic limitations on cloud droplet formation and impact on cloud albedo, Tellus, 53(2), 133-149, 2001.

Penner, J. E., Dong, X., and Chen, Y.: Observational evidence of a change in radiative forcing due to the indirect aerosol effect, Nature, 427, 231-234, 2004.

Petters, M. D. and Kreidenweis, S. M.: A single parameter representation of hygroscopic growth and cloud condensation nucleus activity, Atmos. Chem. Phys., 7, 1961-1971, 2007, http://www.atmos-chem-phys.net/7/1961/2007/.

Phillips, V. T. J., Donner, L. J., and Garner, S. T.: Nucleation processes in deep convection simulated by a cloud-system-resolving model with double-moment bulk microphysics, J. Atmos. Sci., 64, 738-761, 2007.

Pitzer, K. S. and Mayorga, G.: Thermodynamics of electrolytes. II. Acitivity and osmotic coefficients for strong electrolytes with one or both ions univalent, J. Phys. Chem., 77, 2300-2308, 1973.

Pöschl, U., Rudich, Y., and Ammann, M.: Kinetic model framework for aerosol and cloud surface chemistry and gas-particle interactions - Part 1: General equations, parameters, and terminology, Atmos. Chem. Phys., 7, 5989-6023, 2007,

http://www.atmos-chem-phys.net/7/5989/2007/.

Pöschl, U., Rose, D., and Andreae M. O.: Climatologies of cloudrelated aerosols - Part 2: Particle hygroscopicity and cloud condensation nucleus activity, in: Clouds in the perturbed climate system - Their relationship to energy balance, atmospheric dynamics, and precipitation, edited by: Heintzenberg, J. and Charlson, R. J., MIT Press, Cambridge, 58-72, 2009.

Posselt, R. and Lohmann, U.: Influence of Giant CCN on warm rain processes in the ECHAM5 GCM, Atmos. Chem. Phys., 8, 37693788, 2008, http://www.atmos-chem-phys.net/8/3769/2008/.

Pruppacher, H. R. and Klett, J. D.: Microphysics of clouds and precipitation, Kluwer Academics Publishers, 1997.

Ramanathan, V., Crutzen, P. J., Kiehl, J. T., and Rosenfeld, D.: Aerosols, Climate, and the Hydrological Cycle, Science, 294, 2119-2124, 2001a.

Ramanathan, V., Crutzen, P. J., Lelieveld, J., et al.: Indian Ocean Experiment: An integrated analysis of the climate forcing and effects of the great Indo-Asian haze, J. Geophys. Res., 106, 2837128398, 2001b.

Reid, J. S. and Hobbs, P. V.: Physical and optical properties of young smoke from individual biomass fires in Brazil, J. Geophys. Res., 103, 32013-32030, 1998.

Reid, J. S., Koppmann, R., Eck, T. F., and Eleuterio, D. P.: A review of biomass burning emissions part II: intensive physical properties of biomass burning particles, Atmos. Chem. Phys., 5, 799825,2005 ,

http://www.atmos-chem-phys.net/5/799/2005/.

Rissmann, T. A., Nenes, A., and Seinfeld, J. H.: Chemical amplification (or dampening) if the Towmey effect: Conditions derived from droplet activation theory, J. Atmos. Sci., 61(8), 919-930, 2004.
Robinson, R. A. and Stokes, R. H.: Electrolyte Solutions, (revised), London: Butterworth, 1959.

Rose, D., Gunthe, S. S., Mikhailov, E., Frank, G. P., Dusek, U., Andreae, M. O., and Pöschl, U.: Calibration and measurement uncertainties of a continuous-flow cloud condensation nuclei counter (DMT-CCNC): CCN activation of ammonium sulfate and sodium chloride aerosol particles in theory and experiment, Atmos. Chem. Phys., 8, 1153-1179, 2008a, http://www.atmos-chem-phys.net/8/1153/2008/.

Rose, D., Nowak, A., Achtert, P., Wiedensohler, A., Hu, M., Shao, M., Zhang, Y., Andreae, M. O., and Pöschl, U.: Cloud condensation nuclei in polluted air and biomass burning smoke near the mega-city Guangzhou, China - Part 1: Size-resolved measurements and implications for the modeling of aerosol particle hygroscopicity and CCN activity, Atmos. Chem. Phys. Discuss., 8, 17343-17392, 2008b,

http://www.atmos-chem-phys-discuss.net/8/17343/2008/.

Rosenfeld, D.: Suppression of rain and snow by urban and industrial air pollution, Science, 287(5459), 1793-1796, 2000.

Rosenfeld, D.: Aerosols, clouds, and climate, Science, 312, 13231324, 2006.

Rosenfeld, D., Fromm, M., Trentmann, J., Luderer, G., Andreae, M. O., and Servranckx, R.: The Chisholm firestorm: observed microstructure, precipitation and lightning activity of a pyrocumulonimbus, Atmos. Chem. Phys., 7, 645-659, 2007, http://www.atmos-chem-phys.net/7/645/2007/.

Rosenfeld, D., Lohmann, U., Raga, G. B., O’Dowd, C. D., Kulmala, M., Fuzzi, S., Reissell, A., and Andreae, M. O., Flood or drought: How do aerosols affect precipitation?, Science, 321, 1309-1313, 2008.

Ruehl, C. R., Chuang, P. Y., and Nenes, A.: How quickly do cloud droplets form on atmospheric particles?, Atmos. Chem. Phys., 8, 1043-1055, 2008, http://www.atmos-chem-phys.net/8/1043/2008/.

Segal, Y. and Khain, A.: Dependence of droplet concentration on aerosol conditions in different cloud types: Application to droplet concentration parameterization of aerosol conditions, J. Geophys. Rev., 111, D15204, doi:10.1029/2005JD006561, 2006.

Seinfeld, J. H. and Pandis, S. N.: Atmospheric chemistry and physics, Wiley \& Sons, 2006.

Simmel, M. and Wurzler, S.: Condensation and activation in sectional cloud microphysical models, Atmos. Res., 80, 218-236, 2005.

Simmel, M., Trautmann, T., and Tetzlaff, G.: Numerical solution of the stochastic collection equation - comparison of the Linear Discrete Method with other methods, Atmos. Res., 61, 135-148, 2002.

Su, H., Reutter, P., Trentmann, J., Rose, D., Gunthe, S., Simmel, M., Nowak, A., Wiedensohler, A., Achtert, P., Hu, M., Shao, M., Zhang, Y. H., Zhu, T., and Pöschl, U.: Cloud parcel modelling of $\mathrm{CCN}$ activation in megacity air based on observations from Beijing, Geophys. Res. Abstracts, Vol. 11, EGU2009-11107-2, 2009

Trentmann, J., Luderer, G., Winterrath, T., Fromm, M. D., Servranckx, R., Textor, C., Herzog, M., Graf, H.-F., and Andreae, M. O.: Modeling of biomass smoke injection into the lower stratosphere by a large forest fire (Part I): reference simulation, Atmos. Chem. Phys., 6, 5247-5260, 2006, http://www.atmos-chem-phys.net/6/5247/2006/. 
Twomey, S.: Atmospheric aerosols, Elsevier Scientific Pub. Co., 320 pp., 1977.

Wang, P. K.: Moisture plumes above thunderstorm anvils and their contributions to cross-tropopause transport of water vapour in midlatitudes, J. Geophys. Res., 108(D6), 4194, doi:10.1029/2002JD002581, 2003.

Wiedensohler, A., Cheng, Y. F., Nowak, A., Wehner, B., Achtert, P., Berghof, M., Birmili, W., Wu, Z. J., Hu, M., Zhu, T., Takegawa, N., Kita, K., Kondo, Y., Lou, S. R., Hofzumahaus, A., Holland, F., Wahner, A., Gunthe, S. S., Rose, D., and Pöschl, U.: Rapid Aerosol Particle Growth and Increase of Cloud Condensation Nucleus (CCN) Activity by Secondary Aerosol Formation: a Case Study for Regional Air Pollution in North Eastern China, J. Geophys. Res., 114, D00G08, doi:10.1029/2008JD010884, 2009.
Zhang, Y. H., Hu, M., Zhong, L. J., Wiedensohler, A., Liu, S. C., Andreae, M. O., Wang, W., and Fan, S. J.: Regional integrated experiments on air quality over Pearl River Delta 2004 (PRIDEPRD2004): Overview., Atmos. Env., 42(25), 6157-6173, 2008. 